\title{
STRATEGI PENGOLAHAN DATA GPS \\ UNTUK PEMANTAUAN PENURUNAN TANAH : STUDI PEREDUKSIAN BIAS ATMOSFIR
}

\section{Dudy Darmawan ${ }^{1}$, Hasanuddin Z. Abidin' ${ }^{1}$ Rochman Djaja ${ }^{2}$, Mipi A. Kusuma ${ }^{1}$,Irwan Meilano ${ }^{1}$, M.Gamal ${ }^{1}$}

\author{
1) Jurusan Teknik Geodesi - Institut Teknologi Bandung \\ J1. Ganesha 10, Bandung 40132, E-mail : dudy@gd.itb.ac.id \\ 2) Badan Koordiansi Survei dan Pemetaan Nasional (Bakosurtanal) \\ Jl. Raya Jakarta-Bogor km. 46, Cibinong, Bogor
}

\begin{abstract}
ABSTRAK
Pengaruh bias atmosfir pada survei GPS untuk pemantauan penurunan tanah pada suatu wilayah akan semakin signifikan karena adanya perbedaan kondisi meteorologi serta ukuran jaring GPS yang cukup besar sehingga diperlukan pengolahan data yang tepat untuk mereduksi pengaruh dari bias tersebut. Terdapat beberapa metode pereduksian bias atmosfir,antara lain: pemodelan, pengestimasian dan pengamatan.
\end{abstract}

Pada makalah ini akan diuraikan beberapa strategi pengolahan data GPS untuk mereduksi bias atmosfir dengan menggunakan metode pemodelan dan pengestimasian serta kombinasi antara kedua metode tersebut. Selain itu penggunaan data fase GPS menjadi bahan pertimbangan pula dalam kaitannya untuk mereduksi bias atmosfir. Akan ditunjukan bahwa pengestimasian bias atmosfir, tanpa pengamatan kondisi meteorologi, memberikan hasil yang lebih baik ketimbang pemodelan, dimana besarnya efek kesalahan sistematik yang tersisa akibat bias atmosfir pada setiap titik pantau dari hasil pengestimasian berkisar antara $0,8-1,2 \mathrm{~cm}$ sedangkan untuk pemodelan berkisar antara 1,0 - 1,6 cm. asus penurunan tanah di wilayah DKI Jakarta dijadikan sebagai objek studi dimana data GPS untuk survei di DKI Jakarta tahun 1997 dan 1999 diolah dengan menggunakan perangkat ilmiah Bernese 4.0.

\section{PENDAhUluan}

Ketelitian penentuan posisi dengan teknik GPS akan dipengaruhi oleh beberapa efek sistematik atau bias GPS diantaranya, [Hartinger et al, 1999], yaitu ; ketelitian orbit satelit, gangguan perambatan sinyal yang disebabkan oleh lapisan atmosfir, geometri satelit, dan kualitas data. Kemudian, dalam kaitannya dengan perhitungan posisi yang umumnya membutuhkan keberadaan titik ikat sebagai pendefinisian datum posisi, maka kualitas dari titik ikat tersebut menjadi faktor yang juga bisa mempengaruhi ketelitian posisi yang diperoleh. Pada Tabel 1 ditunjukan besarnya pengaruh yang diberikan oleh masing-masig bias secara absolut dan relatif [Beutler et al, 1989].

Berdasarkan Tabel 1 terlihat bahwa besarnya bias yang mempengaruhi tergantung kepada ukuran panjang baseline, makin besar ukuran panjang baseline makin besar pula bias yang berpengaruh. Dalam kaitannya dengan pemantauan penurunan tanah pada suatu wilayah maka panjang baseline serta perbedaan tinggi antar titik akan memiliki ukuran yang besar sehingga bias yang berpengaruh akan bertambah. Dengan demikian perlu dilakukan strategi pengukuran dan pengolahan data yang bisa mereduksi pengaruh dari bias-bias tersebut.

Dari bias-bias yang tercantum pada Tabel 1 tersebut, untuk mereduksi bias karena kesalahan orbit bisa digunakan informasi orbit teliti (precise ephemerides) hasil dari pengamatan dan perhitungan yang dilakukan oleh beberapa stasiun IGS (International 
Geodynamic Service) dengan tingkat ketelitian sampai level mm. Kemudian titik ikat harus ditentukan secara hati-hati untuk menghindari efek dari kesalahan sistematiknya. Hanya bias yang disebabkan oleh efek atmosfir (ionosfir dan troposfir) yang cukup sulit untuk direduksi karena sangat bergantung kepada kondisi meteorologi yang senantiasa berubah dari waktu ke waktu.

Tabel 1. Besarnya pengaruh Bias pada Survei GPS [Beutler et al, 1989].

\begin{tabular}{|l|l|}
\hline \multicolumn{1}{|c|}{ Bias GPS } & \multicolumn{1}{|c|}{ Magnitude bias } \\
\hline Orbit Satelit & $\begin{array}{l}\text { Kesalahan orbit sebesar 1" menyebabkan rotasi } \\
\text { jaringan sebesar 1". }\end{array}$ \\
\hline Troposfir (relatif) & $\begin{array}{l}\text { Bias sebesar 1 mm pada arah zenith menyebabkan } \\
\text { kesalahan pada komponen tinggi (h) sebesar 3 mm. }\end{array}$ \\
\hline Troposfir (absolut) & $\begin{array}{l}\text { Jika bias troposfir pada baseline yang panjang } \\
\text { diabaikan, maka bias sebesar 1 m pada arah zenith } \\
\text { menyebabkan perubahan skala jaringan sebesar 0.3 } \\
\text { ppm. }\end{array}$ \\
\hline Ionosfir (absolut) & $\begin{array}{l}\text { Jika kandungan elektron sebesar 1015/m }{ }^{2} \text { pada arah } \\
\text { zenith diabaikan menyebabkan pengerutan jaringan } \\
\text { sebesar 0. 6 ppm. }\end{array}$ \\
\hline $\begin{array}{l}\text { Titik ikat pada komponen } \\
\text { tinggi }\end{array}$ & $\begin{array}{l}\text { Kesalahan pada komponen tinggi sebesar 10 m } \\
\text { menyebabkan efek skala jaringan sebesar 0.4 ppm. }\end{array}$ \\
\hline $\begin{array}{l}\text { Titik ikat pada komponen } \\
\text { horisontal }\end{array}$ & $\begin{array}{l}\text { Kesalahan sebesar 1" mempengaruhi rotasi jaringan } \\
\text { sebesar 0.1" }\end{array}$ \\
\hline
\end{tabular}

Pada makalah ini akan dibahas beberapa strategi pengolahan data GPS untuk mereduksi pengaruh dari bias atmosfir untuk keperluan pemantauan penurunan tanah. Pembahasan didasarkan kepada hasil-hasil pengolahan data menggunakan perangkat lunak ilmiah Bernese 4.0 dari dua kali survei GPS pada tahun 1997 dan 1999 untuk pemantauan penurunan tanah di wilayah DKI Jakarta.

\section{METODE PEREDUKSIAN BIAS GPS}

Terdapat beberapa metode untuk mereduksi bias GPS, antara lain : pemodelan, pengestimasian serta metode pengamatan. Dalam makalah ini digunakan metode pemodelan dan pengestimasian, oleh karena itu sebagai latar belakang pembahasan berikut ini akan dibahas secara singkat metode pemodelan dan pengestimasian untuk mereduksi bias atmosfir.

\subsection{Model Reduksi Bias Troposfir}

Bias troposfir terbagi kepada dua [Rothacher et al, 1996] yaitu ; (1) bias relatif troposfir; akibat pengaruh refraksi troposfir satu titik terhadap titik lainnya pada suatu baseline.

(2) bias absolut troposfir; akibat pengaruh refraksi troposfir masing-masing titik pada suatu baseline. Dimana bias relatif akan mempengaruhi akurasi dari komponen tinggi sedangkan bias troposfir absolut akan mempengaruhi skala jaringan dimana seolah-olah jaringan tersebut berkontraksi (mengerut atau membesar).

Untuk jaringan yang relatif kecil (local/small network dibawah $20 \mathrm{~km}$ ) efek bias troposfir relatif lebih memberikan efek yang signifikan ketimbang bias absolutnya serta cukup rumit untuk dimodelkan. Jika satelit terdistribusi di atas titik pantau yang diamati maka besarnya pengaruh bias relatif troposfir $\Delta \rho_{r}{ }^{\circ}$ orde pertama pada arah zenith $Z$ terhadap komponen tinggi $\Delta h$ sebagai berikut [Rothacher et al, 1996] :

$$
\Delta h=\frac{\Delta \rho_{r}{ }^{\mathrm{O}}}{\cos \mathrm{Z}}
$$


Sedangkan bias absolut troposfir $\Delta \rho_{a}{ }^{\circ}$ akan mempengaruhi skala jaringan sebesar :

$$
\frac{\Delta \ell}{\ell}=s=\frac{\Delta \rho_{a}^{o}}{R \cdot \cos Z}
$$

dimana s adalah kontraksi/skala yang terjadi pada jaringan/baseline dan R adalah jarijari bumi.

Umumnya untuk menghindari efek sistematik dari phase noise akibat satelit berelevasi rendah selalu digunakan sudut elevasi satelit sebesar $15^{\circ}$. Jika sudut elevasi sebesar $15^{0}$ ini digunakan, maka berdasarkan persamaan (1) dan (2) bisa dilihat bahwa bias relatif troposfir $\Delta \rho_{r}{ }^{\circ}$ sebesar $10 \mathrm{~cm}$ akan mempengaruhi akurasi komponen tinggi sebesar hampir $30 \mathrm{~cm}$ dan skala jaringan akan berubah sebesar $0.05 \mathrm{ppm}$.

Pada kenyataannya cukup sulit untuk membedakan antara bias relatif dan absolut troposfir sehingga lebih umum diggunakan istilah bias troposfir $\Delta \rho^{\circ}$ (yang dibagi menjadi komponen basah dan kering). Untuk menentukan koreksi bias troposfir $\Delta \rho^{\circ}$ digunakan beberapa pemodelan yang bergantung kepada kondisi meteorologi (tekanan $P$, temperatur $T$, kelembaban $H$ serta ketinggian $h$ ) pada saat pengukuran. Pada makalah ini akan digunakan model Saastamoinen untuk mereduksi pengaruh bias troposfir [Rothacher et al, 1996] :

$$
\Delta \rho^{o}=\frac{0.002277}{\operatorname{Cos} Z}\left[P+\left(\frac{1255}{T}+0.05\right) e-\tan ^{2} Z\right]
$$

harga $e$ menyatakan tekanan parsial dari kelembaban udara. Nilai tekanan, temperatur dan kelembaban bisa diturunkan dari model atmosfir standar yang diukur berdasarkan ketingian [Saastamoinen, 1963; Wedyanto et al 1999] :

$$
\begin{aligned}
& P=P_{0}\left(1-0.000226\left(h-h_{0}\right)\right)^{5.225} \\
& T=T_{0}-0.0065\left(h-h_{0}\right) \\
& H=H_{0} \cdot e^{-0.0006396\left(h-h_{0}\right)}
\end{aligned}
$$

dengan nilai $h_{o}, T_{0}, P_{0}, H_{0}$ ditentukan berdasarkan kondisi di titik yang diamati.

\subsection{Model Reduksi Bias Ionosfir}

Pengaruh bias ionosfir $\Delta I$ bergantung kepada frekuensi yang digunakan serta jumlah total kandungan elektron (Total Electrical Content/TEC] E ketika sinyal GPS merambat dalam lapisan ionosfir [Rothacher et al, 1996] :

$$
\Delta I=-\frac{\alpha \cdot E}{f^{2}}
$$

Harga $E$ dinyatakan dengan TEC Unit (TECU) dimana 1 TECU sama dengan $10^{16} / \mathrm{m}^{2}$ kemudian konstanta $\alpha=4.03 .10^{17} \mathrm{~m} \mathrm{~s}^{-2} \mathrm{TECU}^{-1}$. 
Persamaan (5) menunjukan bahwa bias ionosfir berbanding terbalik terhadap frekuensi, sehingga penggunaan frekuensi ganda L1 dan L2 memungkinkan untuk mereduksi bias ionosfir ini.

\subsection{Estimasi Bias GPS}

Cara lain untuk mereduksi bias GPS adalah dengan menyertakan bias tersebut ke dalam persamaan normalnya sebagai parameter yang akan ditentukan bersama-sama dengan koordinat titik. Harga koreksi bias yang diperoleh dengan menggunakan pemodelan umumnya digunakan sebagai harga pendekatan.

Pada makalah ini dilakukan pengestimasian bias atmosfir secara relatif dan absolut. Pada pengestimasian secara absolut besarnya bias untuk masing-masing titik penyusun baseline akan ditentukan harganya, dengan kata lain estimasi absolut berarti mengkoreksi besarnya harga bias atmosfir untuk masing-masing titik.

Sedangkan estimasi secara relatif adalah mengestimasi pengaruh bias atmosfir satu titik relatif terhadap titik lainnya. Untuk mengestimasi pengaruh relatif tersebut, hanya satu titik di ujung baseline yang diestimasi dan titik yang lainnya diasumsikan tidak dipengaruhi oleh bias atmosfir. Untuk jaring yang ukurannya besar estimasi relatif akan memberikan hasil yang kurang baik karena adanya perbedaan kondisi meteorologi dan ketinggian yang besar, hal sebaliknya berlaku bagi ukuran jaring yang kecil pengestimasian relatif memberikan hasil yang lebih baik [Rothacher et al, 1996].

\section{STUDI KASUS}

Fenomena penurunan tanah di wilayah DKI Jakarta bukan merupakan suatu hal yang baru, sudah banyak laporan yang mengindikasikan adanya penurunan tanah di sekitar wilayah DKI Jakarta. Salah satunya laporan dari Departemen Pertambangan yang menyatakan penurunan tanah di beberapa wilayah di DKI Jakarta berkisar antara 20 cm sampai $200 \mathrm{~cm}$ antara tahun 1982 sampai 1997. Fenomena terjadinya penurunan tanah ini bisa terlihat dari banyaknya bangunan yang retak, bertambahnya daerah yang rawan banjir dan menurunnya permukaan air tanah. [Abidin et al, 2000]

Survei GPS untuk pemantauan penurunan tanah di wilayah DKI Jakarta telah dilakukan sebanyak dua kali survei oleh tim peneliti dari Lab. Geodesi Jurusan Teknik Geodesi ITB pada tahun 1997 dan 1999 dengan mengoperasikan 4 buah receiver Ashtech Z-XII3 dan 2 buah receiver Leica SR9500. Sebanyak 12 titik GPS yang ditempatkan di beberapa areal yang diperkirakan mengalami penurunan tanah telah diamati selama kurang lebih 10 jam dengan interval epok selama 30 detik dan sudut elevasi $15^{\circ}$.

Jaring GPS pemantau didesain secara radial dimana setiap titik pantau dalam jaringan baseline-nya diikatkan kepada titik Bakosurtanal (BAKO), kemudian perangkat ilmiah Bernese 4.0 digunakan untuk menghitung solusi vektor baseline tersebut. Distribusi serta desain jaring GPS seperti pada gambar 1.

Beda tinggi antara titik-titik pantau dengan titik ikat BAKO berkisar antara $70-140 \mathrm{~m}$ kemudian perbedaan panjang baseline-nya antara $15-45 \mathrm{~km}$ dengan suhu dan kelembaban rata-rata (pada saat survei) berkisar antara $30^{\circ} \mathrm{C}$ dan $80 \mathrm{Mbar}$.

Utuk mengetahui lebih lanjut mengenai karakteristik penurunan tanah di DKI Jakarta berdasarkan metode pemantauan secara geodetik bisa dilihat di [Abidin et al, 1998; Abidin et al, 2000; Rochman Djaja, 2000]. 


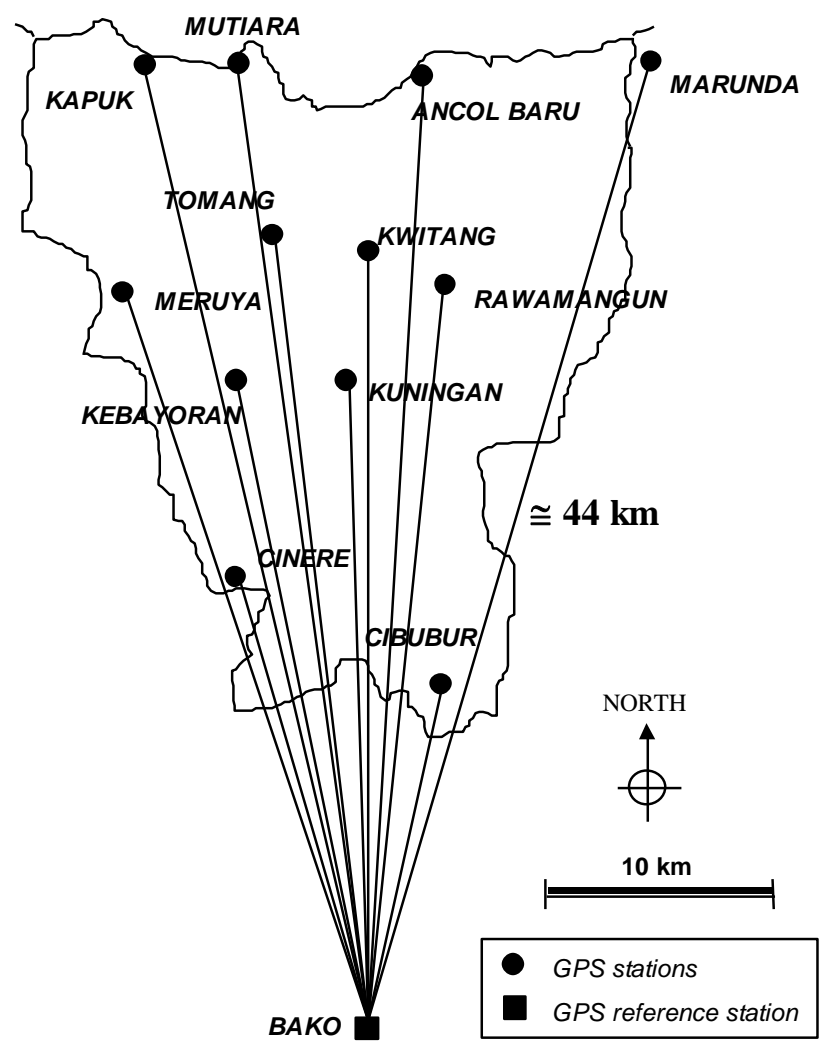

Gambar 1. Jaring Pemantau Penurunan Tanah DKI Jakarta

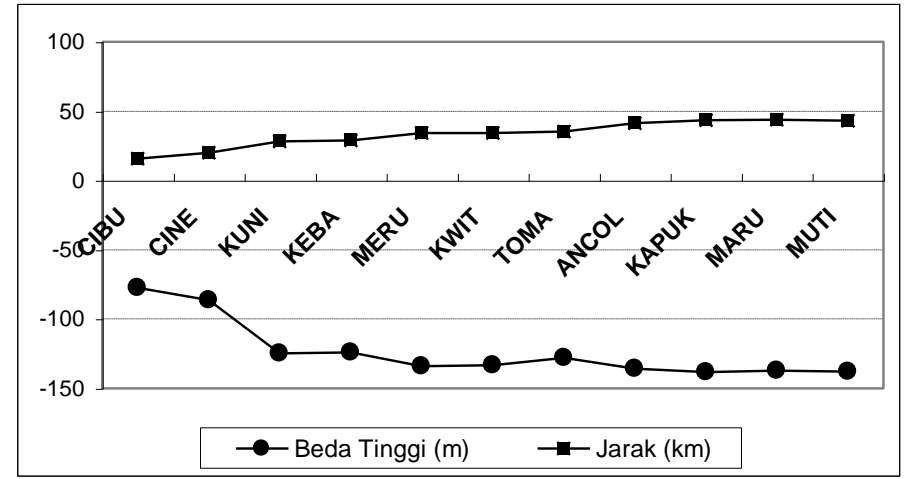

Gambar 2. Grafik Variasi Beda Tinggi dan Panjang Baseline Titik-titik Pantau dari Titik Ikat BAKO

\section{STRATEGI PENGOLAHAN DATA}

Untuk mereduksi bias GPS yang berpengaruh dilakukan beberapa upaya, antara lain; pemilihan kombinasi linier data fase serta pemodelan dan pengestimasian bias GPS.

\subsection{Kombinasi Linier Data Fase}

Seperti telah disebutkan sebelumnya bahwa penggunaan data frekuensi ganda L1 dan L2 dapat mereduksi bias ionosfir. Ada beberapa kombinasi linier data yang masingmasing memiliki kelebihan dan kekurangan. Dalam kaitannya untuk mereduksi bias ionosfir yang berpengaruh akibat baseline yang panjang (lebih dari $20 \mathrm{~km}$ ) digunakan kombinasi linier ionospheric free (L3) yang secara teoritik mampu mengeleminir bias ionosfir namun memiliki phase noise hampir tiga kali lebih besar dari phase noise L1. 
Ionospheric free (L3) merupakan pengkombinasian linier antara kombinasi linier WideLane $\left(\mathrm{L}_{\Delta}\right)$ dan Narrow-Lane $\left(\mathrm{L}_{\Sigma}\right)$, persamaan matematiknya adalah sebagai berikut : [Rothacher et al, 1996]

$$
L 3=\frac{L_{\Delta}+L_{\Sigma}}{2}
$$

Metoda ambiguitas yang digunakan dalam makalah ini adalah metode search yang mampu menghitung nilai integer ambiguitas untuk baseline panjang (sampai $100 \mathrm{~km}$ ) dengan cepat namun metode ini rentan terhadap efek kesalahan sistematik.

\subsection{Pemodelan dan Pengestimasian Bias Atmosfir}

Dalam makalah ini digunakan pemodelan dan pengestimasian serta kombinasi antara keduanya sehingga menghasilkan beberapa kemungkinan model pengolahan untuk mereduksi bias atmosfir, seperti tercantum pada tabel 2 .

Tabel 2. Kemungkinan Model-Model Pengolahan Data

\begin{tabular}{|c|c|c|c|c|c|}
\hline Model & Kombinasi & \multicolumn{2}{|c|}{ Ionosfir } & \multicolumn{2}{c|}{ Troposfir } \\
\cline { 3 - 6 } & Linier & Model & Estimasi & Model & Estimasi \\
\hline A & L3 & & & & \\
\hline B & L3 & Ya & & & \\
\hline C & L3 & & & Ya & \\
\hline D & L3 & & Ya & & \\
\hline E & L3 & & & & Ya (absolut) \\
\hline F & L3 & Ya & & Ya & \\
\hline G & L3 & & Ya & & Ya (absolut) \\
\hline H & L3 & Ya & Ya & Ya & Ya (absolut) \\
\hline I & L3 & & & & Ya (relatif) \\
\hline J & L3 & Ya & Ya & Ya & Ya (relatif) \\
\hline
\end{tabular}

Model ionosfir lokal digunakan untuk mengestimasi jumlah total kandungan elektron $E$ dengan menggunakan data kombinasi linear geomtric free (L4). Sedangkan model koreksi troposfir yang digunakan adalah model Saastamoinen, dengan harga referensi dari temperatur $T_{0}$, tekanan $P_{0}$ dan kelembaban $H_{0}$ berdasarkan nilai rata-rata hasil pengukuran pada titik pantau terendah. Harga-harga yang dijadikan konstanta referensi untuk menentukan model reduksi troposfir adalah sebagai berikut.

$\begin{array}{ll}\text { Tinggi referensi ho } & : 10 \mathrm{~m} \\ \text { Temperatur referensi } T_{0} & : 32^{\circ} \mathrm{C} \\ \text { Tekanan referensi } P_{0} & : 1013.25 \text { mbar } \\ \text { Kelembaban referensi } H_{0} & : 60 \%\end{array}$

\section{PEMBaHASAN}

Pada bagian ini akan dipelajari hasil yang diperoleh dari setiap model terhadap pereduksian bias atmosfir. Parameter yang akan dipelajari adalah kualitas pengolahan data dan kesalahan sistematik, komponen vektor baseline, panjang baseline, serta pengaruh terhadap vektor penurunan komponen tinggi dari hasil dua kali survei. Sebelumnya akan bibahas efektifitas penggunaan kombinasi linier ionospheric free (L3) untuk mereduksi bias ionosfir. Hasil dari pengolahan survei tahun 1997 dijadikan sebagai bahan pembahasan 


\subsection{Ionospheric Free}

Untuk melihat sampai sejauh mana efektifitas dari penggunaan kombinasi linier ionospheric free (L3) akan dilihat hasil yang diperoleh dari model A (tanpa model dan estimasi bias ionosfir dan troposfir) model B (model bias ionosfir) dan D (estimasi bias ionosfir).

Dari hasil pengolahan menggunakan perangkat ilmiah Bernese 4.0 kualitas pengolahan data diindikasikan dengan apa yang disebut Sigma of Single Difference (SoSD), nilai SoSD ini menunjukan besarnya efek sistematik yang tersisa. Nilai SoSD yang diperoleh dari model A, B dan D memberikan hasil yang sama, seperti yan ditunjukan oleh gambar 3, dimana grafik SoSD masing-masing titik untuk setiap model menunjukan bentuk dan besar yang sama. Dari gambar 3.a dan 3.b terlihat bahwa nilai SoSD cenderung semakin membesar dengan bertambahnya panjang baseline dan tidak ada perbedaan SoSD yang signifikan antara CIBU dan CINE. Hal ini menunjukan bahwa kombinasi linear ionospheric free (L3) secara efektif mampu mengeliminir bias ionosfir.

Dari hasil yang diperlihatkan oleh nilai SoSD untuk titik CIBU dan CINE menunjukan bahwa kombinasi linier ionospheric free (L3) lebih efektif bila digunakan untuk mengolah baseline yang relatif pendek $(20 \mathrm{~km})$ dan perbedaan tinggi tidak lebih dari 100 m.

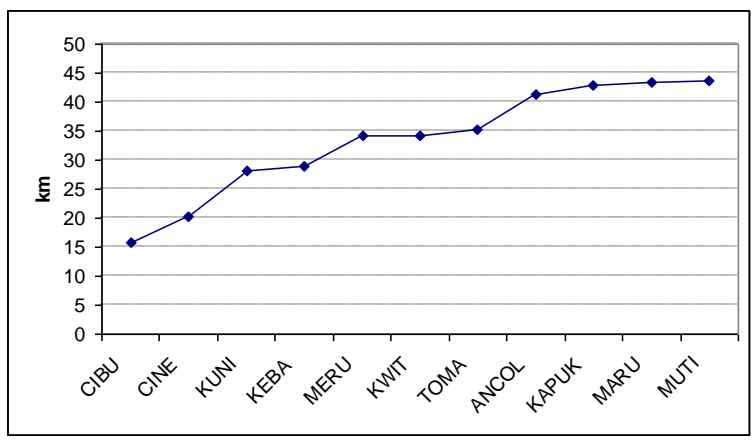

(a)

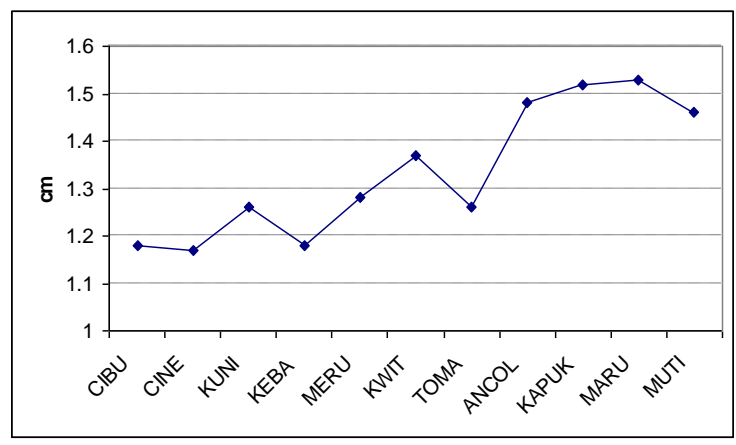

(b)

Gambar 3. Grafik (a) Panjang Baseline dan (b) SoSD

Hasil Pengolahan Model A, B dan D ( grafik berimpit)

Kemudian bisa disimpulkan bahwa tidak diperlukan lagi pemodelan dan pengestimasian bias ionosfir jika digunakan data kombinasi linear ionospheric free (L3). Dengan demikian bisa disimpulkan juga bahwa hasil dari model $\mathrm{C}$ akan sama dengan model $\mathrm{F}$ dan model E akan sama dengan model G, sehingga sejumlah kemungkinan model pengolahan seperti yang tercantum pada tabel 2 bisa dikurangi (dengan menghilangkan kolom bias ionosfir yang telah tereliminir oleh penggunaan data ionospheric free (L3)) menjadi sebagai berikut.

Tabel 3. Model-Model Pengolahan Data

\begin{tabular}{|c|c|c|c|}
\hline \multirow{2}{*}{ Model } & \multirow{2}{*}{$\begin{array}{c}\text { Ambi- } \\
\text { guitas }\end{array}$} & \multicolumn{2}{|c|}{ Troposfir } \\
\cline { 3 - 4 } & Model & Estimasi \\
\hline $\mathrm{A}=\mathrm{B}=\mathrm{D}$ & Ya & & \\
\hline $\mathrm{C}=\mathrm{F}$ & Ya & Ya & \\
\hline $\mathrm{E}=\mathrm{G}$ & Ya & & Ya (absolut) \\
\hline $\mathrm{H}$ & Ya & Ya & Ya (absolut) \\
\hline $\mathrm{I}$ & Ya & & Ya (relatif) \\
\hline J & Ya & Ya & Ya (relatif) \\
\hline \multicolumn{3}{|l}{} \\
\hline
\end{tabular}




\subsection{Perbandingan Antar Model}

Berikut ini akan dipelajari hal-hal yang muncul dari model-model A, C, E, H, I, J dalam pereduksian bias dan efeknya terhadap penurunan tanah.

\subsubsection{Kesalahan sistematik}

Untuk melihat efektifitas tiap model dalam pereduksian kesalahan sistematik akibat bias troposfir, berikut ini ditampilkan grafik variasi nilai SoSD tiap titik untuk setiap model. Dari gambar 4 terlihat bahwa model $\mathrm{E}$ dan $\mathrm{H}$ memberikan nilai SoSD yang relatif lebih kecil dibandingkan dengan model yang lainnya. Kisaran nilai SoSD untuk model E dan $\mathrm{H}$ ini antara $0.8-1.2 \mathrm{~cm}$, sedangkan untuk model yang lain umumnya berkisar antara $1.0-1.5 \mathrm{~cm}$.

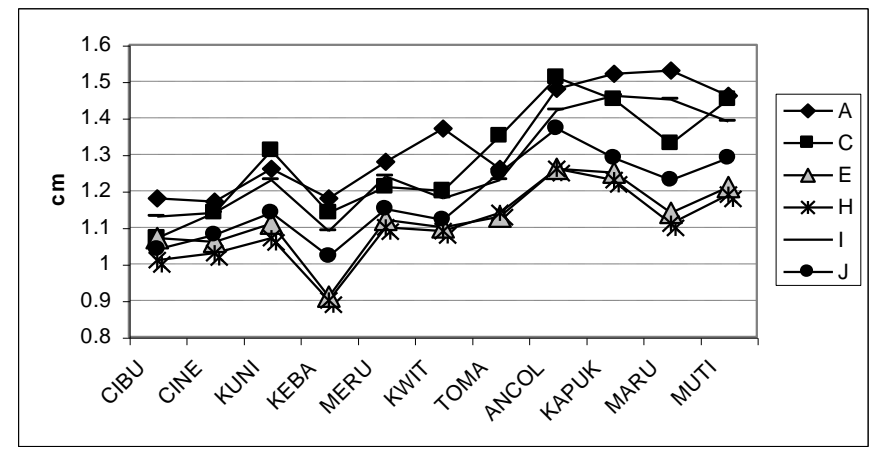

Gambar 4. Grafik Variasi SoSD Tiap Titik pada Setiap Model

Berdasarkan hasil di atas menunjukan bahwa pengestimasian troposfir absolut (model E) dan kombinasi antara pengestimasian absolut serta pemodelan troposfir (model $\mathrm{H}$ ) mampu mereduksi efek sistematik akibat bias troposfir relatif lebih baik dari model yang lainnya. Pengestimasian dan pemodelan troposfir relatif (model I dan J) memberikan hasil yang tidak begitu baik, hal ini kemungkinan besar disebabkan perbedaan kondisi meteorologi yang cukup signifikan dengan titik ikat BAKO sehingga masih menyisakan kesalahan sistematik yang cukup besar.

Jika diperhatikan lebih seksama pada gambar 4 terlihat bahwa nilai SoSD untuk model $\mathrm{H}$ hampir sama besarnya dengan model $\mathrm{E}$, hal tersebut menunjukan bahwa apriori model troposfir dan pengamatan meteorologi tidak memberikan pengaruh yang urgen jika bias diestimasi [Abidin et al, 1998]. Gambar 4 juga menunjukan adanya hubungan antara efek sistematik troposfir dengan panjang baseline, semakin besar panjang baseline maka nilai SoSD cenderung semakin besar. Jika diasumsikan hubungan tersebut adalah non-linier maka gambar 5 berikut ini menunjukan persamaan matematis hubungan antara panjang baseline dan nilai SoSD dari hasil pengolahan model $\mathrm{H}$.

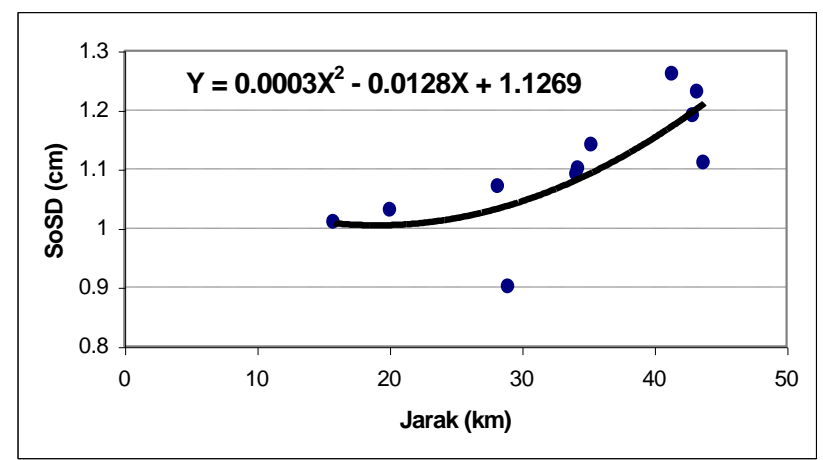

Gambar 5. Grafik Hubungan Antara SoSD dan Panjang Baseline 
5.2.2. Komponen Vektor Baseline

Untuk melihat repeatibilitas komponen vektor baseline, pada gambar 6 berikut ditampilkan simpangan komponen vektor baseline tiap titik terhadap nilai rata-rata dari seluruh model.

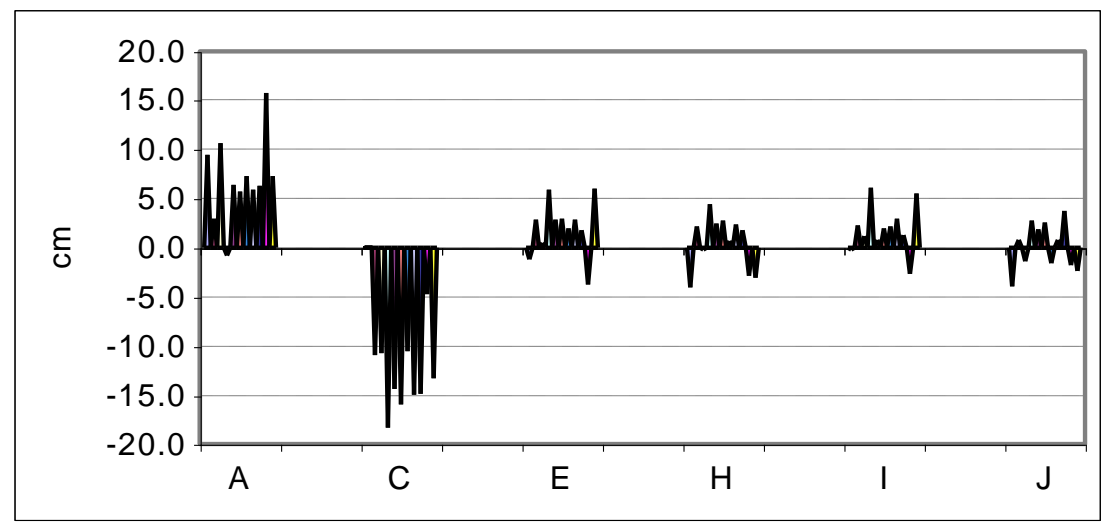

(a) Komponen dh

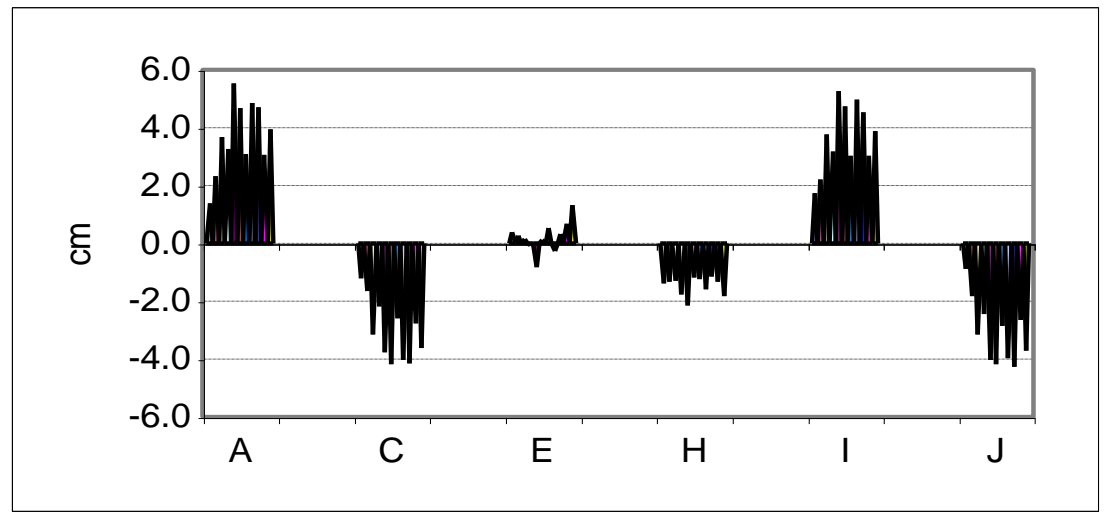

(b) Komponen dL

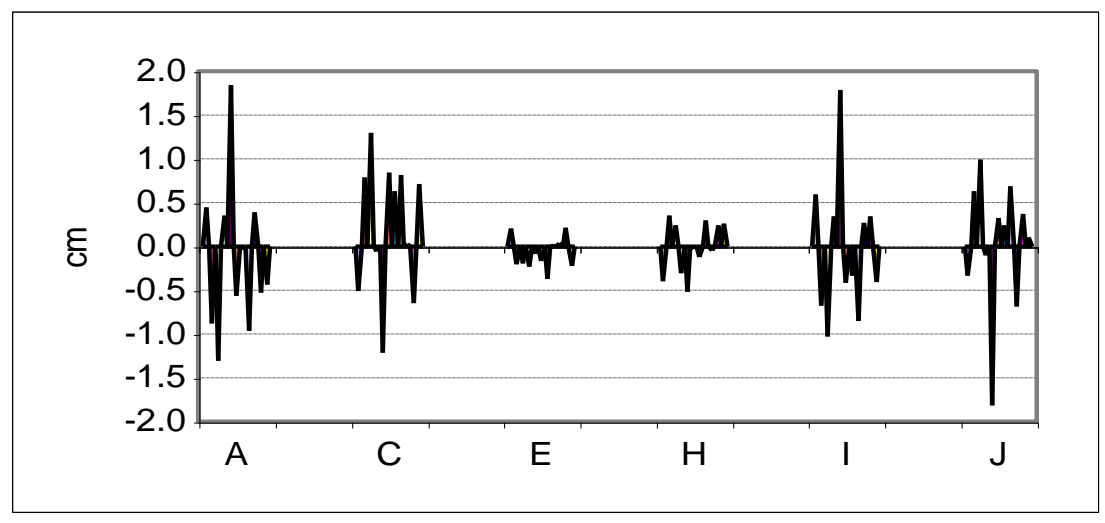

(c) Komponen dB

Gambar 6. Grafik Penyimpangan Komponen Vektor Baseline

Dari gambar 6.a terlihat bahwa model A (tanpa model dan bias troposfir) dan C (model troposfir) memiliki simpangan vektor dh yang lebih besar dibandingkan dengan model yang lainnya. Kemudian dari gambar 6.b dan 6.c terlihat hampir semua model memiliki simpangan yang besar dan relatif hampir sama, meski berbeda tanda positif-negatifnya, pada komponen $\mathrm{dL}$ dan $\mathrm{dB}$ kecuali model $\mathrm{E}$ (estimasi troposfit) dan $\mathrm{H}$ (model dan estimasi troposfir) yang menunjukan simpangan yang berbeda dan relatif lebih kecil dibanding yang lainnya. Berdasarkan hal di atas menunjukan bahwa bias troposfir lebih 
mempengaruhi komponen tingi dh ketimbang dL dan $\mathrm{dB}$. Hal ini bisa terlihat pada gambar 6.a dimana model A yang mengabaikan bias troposfir memiliki simpangan hampir 2 kali lebih besar dibanding model yang memperhatikan bias troposfir (model E, $\mathrm{H}, \mathrm{I}, \mathrm{J})$.

Menarik untuk diungkapkan bahwa simpangan dari model $\mathrm{C}$ (model troposfir) malah memberikan simpangan yang hampir sama dengan model A, padahal bias troposfir telah direduksi dengan menggunakan model Saastamoinen. Hal ini kemungkinan diakibatkan oleh penggunaan referensi untuk parameter meteorologi (suhu, kelembaban, dan tekanan) yang diambil dari pengukuran pada titik terendah tidak cocok untuk mewakili kondisi meteorologi di sekitar wilayah DKI Jakarta. Penyebab lain yang mempengaruhi model $\mathrm{C}$ adalah adanya perbedaan kondisi meteorologi antara titik pantau dan titik ikat BAKO. Perbedaan kondisi meteorologi antara titik ikat BAKO dan titik-titik pantau bisa terlihat dari hasil model $\mathrm{E}, \mathrm{H}$, I, dan $\mathrm{J}$, dimana model $\mathrm{E}$ dan $\mathrm{H}$ (troposfir absolut) yang memperhitungkan kondisi meteorologi di BAKO memberikan repeatibilitas yang lebih kecil pada setiap komponen vektor baseline-nya dibanding model I dan J (troposfir relatif) yang mengabaikan kondisi meterologi di BAKO.

Menurut [Wedyanto, 1994] pereduksian bias troposfir dengan menggunakan beberapa pemodelan bias troposfir (Saastamoinen atau Hopfield) akan memberikan hasil yang lebih baik jika parameter meteorologi yang dijadikan referensi $\left(\mathrm{T}_{0}, \mathrm{P}_{0}, \mathrm{H}_{0}\right)$ diperoleh dari pengamatan setiap titik ketika survei GPS berlangsung. Namun demikian jika tidak ada data parameter meteorologi di setiap titik pengamatan, seperti kasus DKI Jakarta periode 1997-1999, bisa digunakan proses pengestimasian terhadap harga dari koreksi troposfir tersebut. Dari uraian di atas bisa diambil kesimpulan bahwa untuk kasus DKI Jakarta bias troposfir akan lebih baik jika diestimasi secara absolut (model E dan $\mathrm{H}$ ) dengan memperhatikan atau menyertakan kondisi troposfir di sekitar titik ikat BAKO sebagai parameter yang akan dikoreksi.

\subsubsection{Penurunan Tanah}

Untuk melihat pengaruh model-model pengolahan data tersebut terhadap penurunan wilayah di DKI Jakarta, pada gambar 7 di halaman berikut ditunjukan penurunan titik pantau antara tahun 1997 dan 1999 untuk setiap model pengolahan.

Berdasarkan gambar 7 tersebut, hasil yang diberikan oleh model $\mathrm{E}$ dan $\mathrm{H}$ menunjukan bahwa semua titik pantau mengalami penurunan sedangkan hasil yang diberikan oleh model yang lain tidak semua titik pantau mengalami penurunan, ada beberapa titik yang naik dan cenderung stabil. Penurunan yang ditunjukan dari hasil pengolahan model $\mathrm{E}$ dan $\mathrm{H}$ berkisar antara 5 sampai $20 \mathrm{~cm}$ dimana penurunan paling besar terjadi pada umunya di daerah Jakarta bagian utara yang diwakili oleh titik-titik pantau ANCOL (Ancol Baru), PIKA (Pantai Indah Kapuk), MARU (Pantai Marunda) dengan penurunan lebih dari $7 \mathrm{~cm} /$ th, kecuali pada titik pantau MUTI (Pantai Mutiara) yang cenderung stabil.

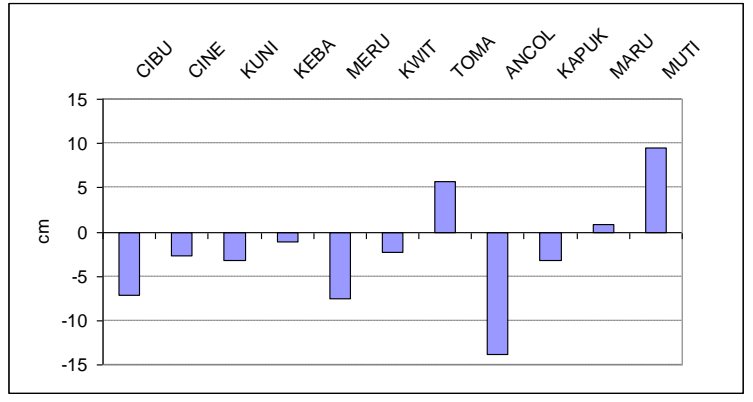

(a). Model A

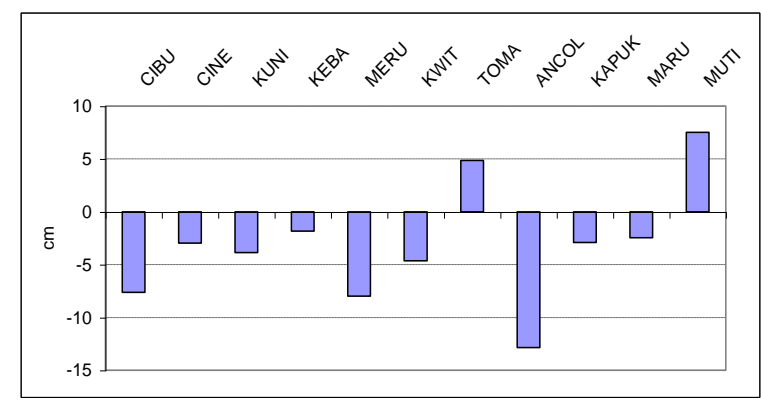

(b). Model C 


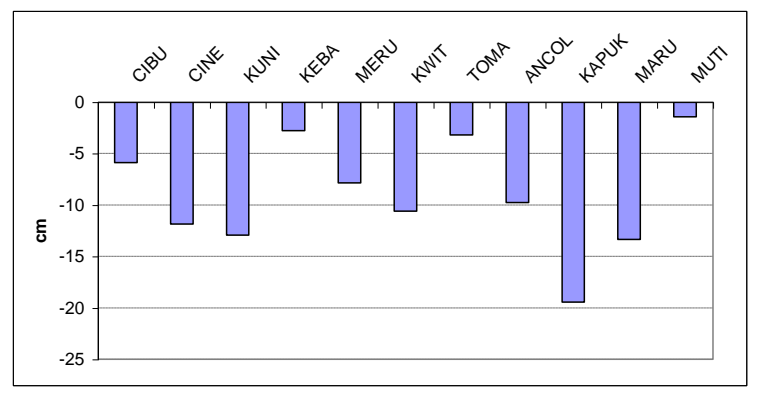

(c). Model E

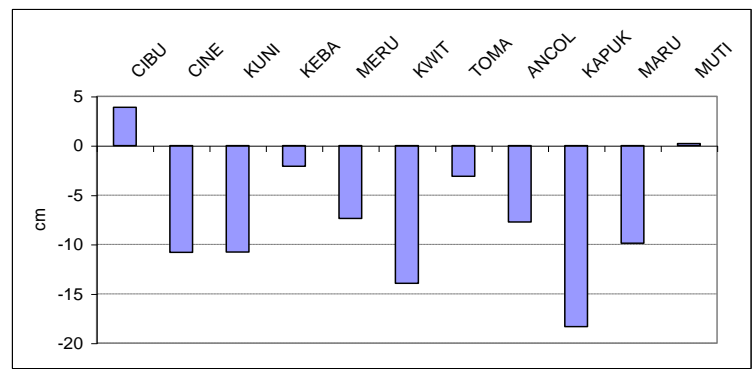

(e). Model I

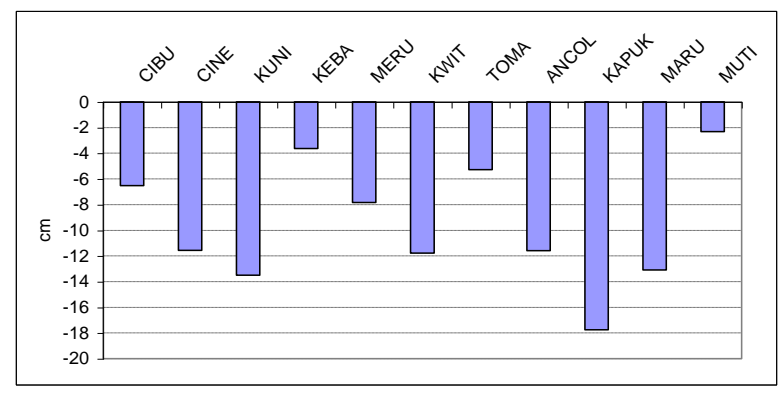

(d). Model H

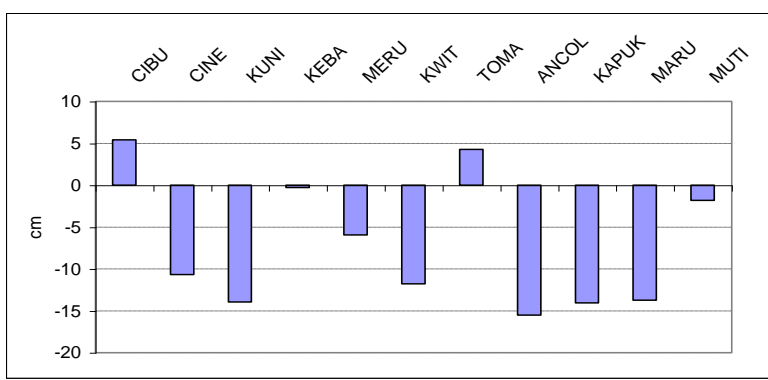

(f). Model J

Gambar 7. Grafik Penurunan Titik Pantau DKI Jakarta Periode 1997-1999

Hasil Pengolahan Setiap Model

\section{PENUTUP}

Berdasarkan hasil-hasil perhitungan serta analisis yang telah diuraikan di atas, ada beberapa hal yang dapat disimpulkan ataupun saran-saran yang berkenaan dengan topik pembahasan, antara lain :

1. Penggunaan kombinasi linier data yang digunakan akan mempengaruhi efektifitas pereduksian bias atmosfir, oleh karena itu perlu ditentukan secara hati-hati berdasarkan kepada ukuran panjang baseline dan kondisi meteorologi pada saat pengamatan. Untuk ukuran baseline yang relatif pendek $(20 \mathrm{~km})$ dan perbedaan tinggi tidak lebih dari $100 \mathrm{~m}$ kombinasi linier ionospheric free (L3) lebih efektif digunakan untuk mereduksi bias ionosfir. Namun meski demikian masih perlu dilakukan pengkajian lebih lanjut terhadap penggunaan kombinasi linier yang lainnya mengingat kombinasi linier ionospheric free (L3) meski mampu mengeliminir bias ionosfir namun memiliki efek sistimatik yang besar.

2. Untuk pemantauan penuruan tanah di DKI Jakarta pengestimasian secara absolut memberikan hasil yang lebih baik dibanding pengestimasian secara relatif.

3. Perlu dilakukan kajian yang lebih lanjut untuk membandingkan efektifitas pemodelan dan pengestimasian dalam mereduksi bias troposfir menggunakan data meteorologi hasil pengamatan di setiap titik pantau.

4. Hasil yang diperoleh dari makalah ini hanya membahas aspek geometrisnya dari penurunan wilayah di DKI Jakarta, perlu dikaji lagi aspek geologisnya untuk melihat korelasi antara vektor penurunan titik pantau dari hasil beberapa model pengolahan dengan kondisi yang sebenarnya.

5. Akhirnya perlu ditekankan bahwa hasil yang diperoleh diverifikasi lagi dengan jaring GPS yang lainnya. 


\section{UCAPAN TERIMA KASIH}

Penulis mengucapkan terima kasih kepada Kosasih Prijatna, M.Sc dan Dr. Wedyanto Kuntjoro yang telah meluangkan waktu dan fikirannya untuk memberikan kritikan, saran dan diskusinya yang berharga dalam penulisan makalah ini.

\section{DAFTAR PUSTAKA}

Abidin, H.Z, O. Yolanda, I. Meilano, O. K. Suganda, M. A. Kusuma, D. Muhardi, B. Setyadji, R. Sukhyar, J. Kahar, T. Tanaka (1998), Efek Bias Troposfir pada Pemantauan Deformasi G. Guntur dengan Metoda Survei GPS, Proceeding ITB Vol. 30 No 1, Bandung.Abidin, H.Z., M.A. Kusuma, I. Meilano, M. Arief Nurdin, Dudy Darmawan, Agus Bintoro, J. Kahar (1998), Pemantauan penurunan tanah di wilayah Jakarta dengan metode survei GPS. S\&P, Majalah Survei dan Pemetaan, Majalah Ikatan Surveior Indonesia, ISSN : 0125-9466, Vol. XII, No.3, Juni, pp. 45 $-56$.

Abidin, H.Z, Rochman Djaja, Dudy Darmawan, Samsul Hadi, Arifin Akbar, I. Meilano, M. A. Kusuma, J. Kahar, Cecep Subarya [2000], Land Subsidence Of Jakarta (Indonesia) and its Geodetic Monitoring System, Paper submitted to Natural Hazard.

G. Beutler, I. Bauersima, S. Botton, M. Rothacher, W. Gurtner, T. Schildnecht [1989], Accuracy and Biases in the Geodetic Application of the Global Positioning System, Manuscripta Geodaetica 14:28-35.

Hartinger, H, Brunner, F.K. (1999), Variances of GPS Phase Observations: The SIGMA- $\varepsilon$ Model, GPS Solutions, Vol.2, No. 4, pp 35-43.

M. Rothacher, L. Mervart [1996], Bernese 4.0 GPS Software, Astronomical Institute University of Berne, Bern.

M. Rothacher, T.A. Springer, S. Schaer, G. Beutler [1997], Processing Strategies for Regional GPS Network, Paper presented at the IAG General assembly, Rio, Brazil.

R. Leitinger, E. Putz [1987], Ionospheric Refraction errors and Observables, Paper presented at IUGG, Vancouver.

Rochman Djaja. (2000) Penelitian Deformasi Vertikal Muka Tanah; Studi Kasus Wilayah Jakarta, http://www.gd.itb.ac.id/laboratoriumutama.htm.

W. Gurtner, G. Beutler, S. Botton, M. Rothacher], A. Geiger, H.-G. Kahle, D. Schneider, A. Wiget [1989, The Use of the Global Positioning System in Mountainous Areas, Manuscripta Geodaetica 14:53-60.

Wedyanto Kuntjoro (1994), A Study of Tropospheric Delay of Radiowave in GPS Observatiuon, A Case Study Yayoi-Nobeyama Baseline, Master Thesis. Geophysics Division, Faculty of Science, The University of Tokyo.

Wedyanto Kuntoro, Mipi A Kusuma, Irwan Meilano, Oskar Yulanda (1999), Penentuan Delay Gelombang Elektromagnetik di Troposfir, Studi Kasus Gunung Guntur dan Sekitarnya, Laporan Penelitian No. 19515198 DIK-ITB Tahun Anggaran $1998 / 1999$. 